\title{
Mind the gap: Health reporting in the Pacific
}

\section{AABSTRACI}

Previous research on developing health journalism in the Pacific region has encouraged journalists to think outside the box when it comes to reporting health, and to view it as more than just drugs and doctors. Factors such as politics, economics, religion, education, gender inequality and traditional cultural taboos influence health outcomes to varying degrees. This perspective on health provides an extensive list of news and feature stories for the media, and yet, this wider focus on the determinants of health is not what drives health journalism in many Pacific countries. This article uses a case study of press coverage of HIV in Papua New Guinea from 2000-2010 to show how coverage of HIV or other communicable diseases in the Pacific need a much wider frame than that of drugs and doctors.

Keywords: health communications, health journalism. HIV journalism, Papua New Guinea, internet audiences, social and economic determinants of health, media coverage of HIV, newsroom practices.

TREVOR CULLEN

Edith Cowan University

$\mathrm{H}$

EALTH is an important topic that affects everyone, either through their own personal experiences or those of their family, friends or work colleagues. Indeed, people are more interested in what hits closest to home, and they want information that is accurate and they can trust. Yet, for a long time, reporting health consisted largely of statistics on the number of deaths and cases of disease, or reporting on epidemiological data that affect people we do not know. While this is important for health officials, it is of little interest to audiences who demand information that is useful to their daily lives.

An added problem that journalists in many Pacific countries face is that they rely heavily on a diet of press releases, workshop invitations and event 
launches to drive their health news. In an article on health journalism in the Pacific, Gooch and Williams-Lahari (2008) argue that health is much more than drugs and doctors, and they list a series of factors that influence health such as gender inequality, good governance, human rights legislation, the changing role of culture, traditional taboos around sexuality, the influence of faith-based organisations, migration and national development (Gooch and Williams-Lahari, 2008, p. 77). This perspective on health provides a new and extensive list of news and feature stories for print, online and broadcast journalists. But this wider focus on the social determinants of health is not what drives health journalism in many Pacific countries.

While there is insufficient data on the extent of public interest in health information in the Pacific region, there has been a steep rise in the United States. Health Online 2013, a national survey of online health information in the United States, was released by the Pew Research Centre's Internet and American life Project in January 2013. It revealed that while 81 percent of American adults use the internet, 59 percent said they searched online for health information in 2012. The data was collected from a telephone survey of more than 3,000 adults living in the United States from August 7 to September 6,2012 . The survey only measured the scope the number of users in contrast to the outcomes of such activity (Pew Internet and American Life Project, 2013, p. 2).

While the Health Online 2013 survey revealed the extent of interest in health information, the researchers did not examine or evaluate the content or credibility of such information. One researcher who has tried to do this is Professor Gary Schwitzer. He runs the Health News Review website, which evaluated more than 1000 health stories in the US media. His May 2010 findings included a damning critique of the media's approach to covering health and medicine. Schwitzer (2010) argued that journalists tended to be cheerleaders rather than providing a critical analysis of health stories. He said there were too many fluffy, feel-good pieces, and unquestioning, awe-struck stories about breakthroughs, and not enough questioning of claims, investigating of evidence, and looking at conflicts of interests, especially with particular sources.

Another survey by the Australian Centre for Independent Journalism in Sydney analysed more than 200 health stories in the Australian press during a one-week period in September 2009, and found that more than half the stories were driven by PR events or media releases (Duxfield, 2010). Also, a 2009 
survey of health stories in The Australian, The Sunday Times and The West Australian by health journalism students at Edith Cowan University discovered a similar pattern - an unhealthy reliance on media releases (Callaghan, 2010).

Several researchers argue that when it comes to health news, sober, reliable and expert reporting can be hard to find. As newsrooms cut numbers and reduce the time available for writing about health, there is often a rush to produce pre-packaged stories, using wire services or relying on media releases as the primary and often only sources of research news (Mooney \& Kirshenbaum, 2009; Raward \& Johnston, 2009; Salleh, 2009; Young, 2009).

Increasing reliance by reporters on embargoes, press releases and wire copy encourages lazy journalism and bland reporting. Davies (2008a) highlights the danger of media groups relying too heavily on wire services, which may have a small pool of reporters producing high-speed but limited 'in-depth' reports, which then receive wide coverage. As journals adopt the use of publicity machines to promote their research, media outlets and wire services have every reason to rely too heavily on the easy media release to save time and effort in preparing science and health stories (Davies, 2008a; 2008b; Mooney and Kirshenbaum, 2009; Murcott, 2009; Orange, 2008).

Also, the engagement of PR firms in health organisations, the selective press releases sent out by medical organisations to the media, and the costcutting approach of media organisations, all foster what former Guardian reporter Nick Davies calls 'churnalism' - the churning out of stories with limited, if any actual reporting by the journalist:

More than ever in the past, we are likely to engage in the mass production of ignorance because the corporations and the accountants who have taken us over, have stripped out our staffing, increased our output and ended up chaining us to our desks so that generally we are simply no longer able to go out and make contacts or find stories or even check facts. (Davies, 2008b)

It should, however, be noted that much communication management, and PR output, is undertaken by organisations which try to ensure that information is well explained. This includes many not-for-profit organisations, research laboratories, socially responsible pharmaceutical companies and public hospitals.

Another area of concern is how narrowly health stories are framed, with 
little or no reference to the social and economic determinants of health. For example, a study of media coverage of obesity in television news in Australia focused attention on personal responsibility for weight loss without reference to structural issues such as: economic pressures to work long hours in sedentary jobs; urban planning that fails to facilitate physical activity; poor public transport and inadequate provision of cycle paths; and inadequate provision of parks and other recreational facilities (Bonfiglioli et al., 2007, p. 442). Yet the neglect of environmental and structural solutions suggests advocacy efforts may be needed to draw attention to how these factors, cumulatively, constrain individual choices and contribute to the obesity epidemic (Bonfiglioli et al. 2007, p. 442).

Admittedly, this last point could be viewed as moving towards health promotion rather than the traditional journalist's role of reporting the facts. But with serious health epidemics such as adult diabetes, is it enough to report only 'what' is happening and omit 'why' it is occurring? Which would provide a better understanding of the disease and ways to deal with it?

\section{The determinants of health provide context and understanding}

Often health stories are framed too narrowly, with little or no reference to the broader determinants of health - social, economic, cultural, religious and political factors - which provide both context and a better understanding of communicable and non-communicable diseases. As early as 1986, with the adoption of the Ottawa Charter, the social and cultural dimensions of health became increasingly more mainstream. In recent years social scientists have come to realise that socio-cultural factors influence complex health behaviours. Take, for example, the relationship between sexual behaviour and HIV infections. Beyond an individual's own social network, there are larger structural and environmental determinants that affect sexual behaviour, such as living conditions related to one's employment. Also, in some countries, there is a lack of sexually transmissible disease services, and condoms can be costly or unavailable. This puts pressure on many sex workers to act in unsafe ways to keep customers satisfied. All of these work against people adopting safer behaviours.

Kippax (2007, p. 5) argues that individual behaviour and 'choice' is always mediated and structured by social relationships, which are in turn influenced by important differences of community, social status, class and other structural 
differences, such as gender and age. In other words, individual behaviour is always contextual, always socially embedded (p. 5).

This is not a new insight. The UN Educational, Scientific and Cultural Organisation (UNESCO) echoed this view back in 2001:

This [HIV] epidemic has become a major developmental challenge that goes beyond the realm of public health. The emerging complexity of the epidemic has made it an issue that touches all aspects of human life. And the perspectives are diverse: medical, human rights, ethical, legal, religious, cultural and political. (UNESCO, 2001, p. 20)

This shift in thinking forms a key part of the Social Change Communication (SCC) theory, where the focus is on seeing people and communities as agents of their own change. This theory is based on a belief that behavioural change is dependent on social change and is a long-term process (Deane 2002, p. 1). The social communication approach to understanding HIV and the need to highlight the context in which the epidemic is embedded, has wide support (McKee et al, 2004, p. 41).

The implications of SCC theory, if adopted by editors and journalists, would widen the predominant narrow framing of HIV stories from a focus primarily on doctors and drugs to one that covers related issues, such as gender equality, domestic violence, inadequate access to treatment, poor health facilities, complex sexual networking, and challenging governments on their policies towards treatment, human rights and overall strategies. From this perspective, the list of potential 'health' stories is enormous.

Not everyone agrees, however, and questions remain about the role of journalism in health promotion and development contexts. For example, how do the media address extremely complex questions such as gender power and the connections between rising health costs and ecological sustainable development? While this remains an ongoing debate, the author still thinks this approach broadens the scope and context of health stories, and leads to a better understanding and discussion of effective measures to deal with communicable diseases such as HIV, sexually transmitted infections and tuberculosis. The findings from a content analysis of press coverage of HIV in Papua New Guinea from 2000 - 2010 are used to highlight these points, and track the gradual adoption of some social and economic determinants of health in the coverage of HIV. 


\section{Press coverage of HIV in PNG-widening the frame}

The story of HIV is one of critical importance in many countries throughout the world. PNG has a serious HIV epidemic, with up to 96 percent of all HIV infections in the Pacific region. Up to 1.8 percent of the adult population in PNG is infected with HIV and prevalence in urban areas may be as high as 3.5 percent (UNAIDS 2012). New infection rates have increased about 30 percent each year since 1997. The author chose PNG as an example because he conducted an extensive longitudinal content analysis of press coverage of HIV in the country's two daily newspapers from 2000 to 2010 (Cullen, 2010). One aim was to discover whether the journalists had tried to include the determinants of health in their HIV stories, rather than just report official facts and figures.

The focus on press coverage of HIV rather than a wider study on media coverage of the disease is due, in large part, to more effective access to archival print data. Print copy is easier to locate and avoids the long arduous task of trawling through broadcast tapes of the 1990s, when transcripts were not readily available. Also, newspapers are influential because news stories that appear in print or online are frequently used by radio and television news editors to provide background - and often actual content - for their daily broadcast news services. In addition, the press can keep issues and debates in the public forum, and move items onto and up the political agenda.

It is evident from the data on press coverage of the disease in PNG from 2000 to 2010 that a disproportionate emphasis was placed upon reporting infection rates, international funding and regional workshops, with little indepth analysis of the disease or educational content (Cullen, 2010, p. 171). Anna Solomon,(2002), a former newspaper editor in PNG, acknowledged that framing the disease in this way had narrowed debate of the topic and led to a lack of interest among readers. Solomon urged her fellow PNG journalists and editors to use imagination, initiative and sensitivity as a way to widen and inevitably improve the reporting of HIV in her country.

In time, slight changes began to emerge. A content analysis by the author (Cullen, 2007) analysed all online news items on HIV from the websites of the country's two national daily newspapers, Post-Courier and The National, during a three-month period from September to November 2007. Surprisingly, while stories on HIV were similar in content to the author's earlier studies on press coverage of HIV in PNG (Cullen 2000, 2005), there was a new focus 
on domestic violence, with both newspapers including 10 items each on the topic in October and November 2007. This represented, for the first time, a small shift in the reporting of HIV in PNG and suggested that journalists had begun to link HIV with the wider social and cultural context of the disease.

The author also analysed all online news items on HIV from the websites of the country's two national newspapers during a three-month period from January to March 2010 (Cullen, 2010). This revealed an interesting trend in the coverage - the recognition of the social stigma surrounding people with HIV in PNG. Several articles coded 'Person Living With AIDS' (PLWA) made it clear that the person described with the disease was not at fault. One notable article in the Post-Courier described the road to infection of a 29-year-old woman from Balimo who became the second wife of a 'well-built man who was a land-owner' from the region. It was only after her husband began losing weight rapidly that she discovered he had been diagnosed with HIV some time earlier, but had not disclosed it. The article directly addressed the societal pressure on her-both to remain with her husband and to hide the disease:

She went back to her family and they are supportive in the situation and want to help raise [her HIV-infected daughter] who is four years old. She said she disclosed her status to the community and to date had not suffered stigma. The community is supportive and I believe that is due to ongoing awareness of the virus," she said. (Post-Courier, March 7, 2010,p5)

Such stories help to demystify the disease and gradually lessen the paralysing fear associated with it.

\section{The missing links}

While the press in PNG is slowly beginning to link the disease with the larger social and cultural context, there are other connected stories that are unreported - such as gender equality - which reflect the complexity of the HIV situation in a developing country such as PNG, and expose how difficult it is to prevent and slow the spread of disease. For example, sexual relations lie at the heart of the HIV epidemic in PNG. Women's lack of social or economic authority is underwritten by the sexual economy and enforced largely by violence. Current attitudes to sex pose serious barriers to the effectiveness of HIV interventions. Women in general, and those involved in sex work in 
particular, are blamed for HIV infection in PNG. It is true that this attitude is not limited to PNG, but also exists even in more developed countries. But the constant public scapegoating of sex workers has further entrenched the view that HIV can be attributed to 'filthy' and 'immoral' women. And yet, it is estimated that almost half of PNG men pay for sex at some time each year (Smith \& Cohen, 2000, p. 6).

For the same reasons, married women are the largest group of women at risk of HIV infection. Further, since most infected women are of childbearing age, they also carry the risk of infecting their children. These issues are directly linked to HIV and yet, until recently, there was rarely a news story or feature article on the topic in PNG's two main newspapers. It is difficult to give a clear explanation for this omission other than to state that gender equality was not considered newsworthy by the editors. Yet, in-depth articles could expose the serious gender inequality in PNG and argue that if married women are to protect themselves and their children in such circumstances, they need precisely the same things as women need in general-access to education and training, removal of restrictions on employment, access to banking services, and credit on their own surety. In addition, they require drastic shifts in property rights, rights of divorced and widowed women, child custody rights, and protection against physical violence. The HIV epidemic is not simply about public health - it also is about basic human rights. There is a need, therefore, to ensure that when reporting on the HIV epidemic, wider links such as poverty reduction and gender equality are part of the coverage.

Other issues include the fact that, with increasing healthcare costs in countries hard hit by HIV, there is immense pressure to generate more income through mining, forestry and other environmentally degrading sources. Increased exploitation of natural resources will mean further degradation of water and ecosystems on which people depend for survival; so poverty increases, and the whole cycle of poverty fuels HIV transmission. Also, when family members in urban areas fall sick they often return to their villages, putting additional pressure on scarce resources and fragile environments. How many journalists in the Pacific would think of reporting these issues, or are able to link these issues to HIV? This is not due to an unwillingness to report, but rather a lack of awareness about the wider links to HIV.

Unfortunately, the narrow conception and understanding of HIV to date has led to missed opportunities for wider coverage and debate. HIV, like other 
communicable diseases, such as sexually transmitted infections, is not merely a medical problem, but operates like a magnifying glass on the exploitation of women, domestic violence, gender inequality, illiteracy, the lack of health facilities, and the kind of rampant poverty that forces people to migrate.

Shining the spotlight on how local governments are coping - or not coping - with HIV is also vital. Political leadership has proved a vital component in the struggle to stem the rise of HIV infections in other parts of the world. This is clear from the decline of infections in Uganda, Thailand and Gambia, where the political leaders have spoken openly and constantly about the epidemic. This has helped lessen the stigma surrounding HIV/AIDS in local communities, and has galvanised these leaders into action as they defined the struggle against HIV as a national cause and campaign.

\section{Obstacles to improving coverage of HIV and other health stories.}

Since the late 1980s, academic research on journalism's roles and responsibilities, news selection processes and new vales in relation to HIV, frequently points to organisational constraints and traditional newsgathering practices as real obstacles to improving the informational and educational content of news stories on HIV. The general staff reporter does not know a great deal about HIV. With very few exceptions, journalists do not have specialist knowledge in the field they report on. This is not a matter of low standards for the occupation but an explicit recognition by newsroom editors that specialist knowledge is not required to get the job done. Specialist knowledge can be counter-productive, leading the reporter to look for complexity and to qualify information, when what news discourse requires is a simple transformation into common sense (Nelkin, 1989, p. 61). Journalists are constantly under pressure from their newsroom editors who want definitive answers. This desire for certainty often leads journalists to convey the idea that science is a solution to the problem of complicated issues (Nelkin 1989, p. 60).

Mcllwaine (2001) emphasises that the imperatives of journalism differ from those of health professionals. Newsmakers are interested in the novel, the sensational, the human-interest angle and the dramatic (Mcllwaine, 2001, p. 168). This tension between journalists and health professionals is clearly stated by Lupton et al, (1993, p. 6). Referring to journalists, these researchers state: 'Their task is to sell their commodity-news-not to serve as the campaigning arm of health education bodies. The manner in which journalists report 
issues such as HIV can therefore detract from the goals of health educators' (p. 6). It is, moreover, generally recognised that educating the public about HIV is not solely the responsibility of media. Also, scientists and public health officials have often done poorly in educating and cultivating journalists and in trying to be accessible and share information (Miller \& Williams, 1993, p. 136).

Several other factors that limit the media's ability to report on health include lack of time and column space, the need to interpret complex research data, statistics and terminology, and difficulty getting access to expert opinions. However, the largest reason is the way the internet has revolutionised the media over the past decade.

As the internet changes the way people access news, traditional media has also changed. The shifting format of reporting, where stories are simultaneously used for traditional media as well as the internet, means news reporters are often called upon to comply with shorter timelines. Where print journalists once worked to daily deadlines, their newspaper websites are now updated regularly through the day as well as when news breaks, giving reporters little time to prepare their stories. Add to this a reduction in staff and a shortage of health reporters. (Wilson, 2012)

Some practical ways to improve this situation could include the introduction of health journalism as part of the tertiary journalism education curriculum in Australia. At present, only one university in Australia (Edith Cowan University in Perth) teaches health journalism. This is the place to start training future health journalists, especially as there is a need for trained health and medical journalists. Also, journalists should engage more with science and medical researchers. Journalists are having an increasingly hard time producing high-quality health stories. Medical journal articles feature in many health stories but new research shows their media releases may contribute to poor quality news (Whitehouse, 2013). Another step might involve the restart of Media Doctor Australia, a website that graded the content of health stories in the media on treatment and drug use from 2005 to 2012.

\section{Conclusion}

There is a growing demand for health information and increasing numbers of people, especially those who go online, make decisions on their health from 
what they read, hear or view (Pew, 2013). This places a real responsibility on journalists to report health information in an accurate and reliable manner. Although there is insufficient data to access public interest in health in the Pacific, surveys in the US and Australia that examined the state of mainstream and online health reporting, exposed the extent of spin, the lack of medical evidence, and the narrow frame and context of many health stories, with little or no reference to the social determinants of health.

There is also a need to widen the narrow frame and focus of many health stories through the inclusion of the determinants of health and human behaviour. This article used the findings from a longitudinal study of the reporting of HIV in PNG's two national newspapers (Post-Courier and The National) from 2000-2010, as an example to show that HIV is not merely a medical problem about drugs and doctors: it is linked to culture, poverty, religion, education, finances and politics. These connections have important implications for political and financial reporters, editorial page writers, television producers and radio journalists, especially if they want to engage in meaningful coverage of the HIV epidemic and its broader ramifications. The most challenging aspect for health journalists in the Pacific is to realise the complexity and interconnectedness of the web of issues linked to reporting HIV, and also, to investigate the wider links to other communicable diseases in the community such as sexually transmitted infections and Tuberculosis. Similar links may be found for even non-communicable diseases such as diabetes and heart disease, which are two diseases that have risen rapidly in recent years throughout the Pacific region.

\section{References}

Bonfiglioli. C., Smith B., King L., Chapman, S. \& Holding, S. (2007). Choice and voice: Obesity debate in television news. The Medical Journal of Australia, 187(8), 442-5.

Brodie, M., Hamel, E.B., Kates, L.A., Altman, J. \& Drew, E. (2004). AIDS at 21: Media coverage of the HIV epidemic. Columbia Journalism Review, 42(6), A1.

Callaghan, R. (2010). Health journalism: Students unravel the hype and laziness in health research reporting. Peer reviewed conference paper delivered at the Journalism Education Association of Australia conference. Perth, Australia, December 1.

Cullen, T. (2000). Repeating mistakes: Press coverage of HIV/AIDS in Papua New Guinea and the South Pacific, unpublished PhD thesis, St Lucia: University of Queensland. 
Cullen, T. (2005). Press coverage of HIV in PNG: Is it sufficient to report only the news? Australian Studies in Journalism, 15, 133-50.

Cullen, T. (2007). Twenty five years of reporting HIV: What can Pacific journalists learn? Peer-reviewed paper presented at the JEANZ conference in Wellington, New Zealand, December 11.

Cullen, T. 2010. 'Reporting HIV in Papua New Guinea: Trends and omissions from 2000-2010', Pacific Journalism Review, 16(2), 163-78.

Davies, N. (2008a). Churnalism has taken the place of what we should be doing: Telling the truth. Retrieved on 20 October, 2012 from www.pressgazette.co.uk/ story.asp? storycode $=40117$

Davies, N. (2008b). Our media have become mass producers of distortion, Retrieved on 10 October, 2012 from www.guardian.co.uk/commentisfree/2008/feb/04/commentpressandpublishing

Deane, J. (2002). Approaches to HIV and AIDS communication strategies. Retrieved on 7 January, 2013, from http://www.healthcomms.org/comms/hiv-aids/hiv02.html

Duxfield, F. (2010). Spinning the media: Spin doctors have plenty to say in health reporting. Retrieved on 28 November, 2012, from http://www.crikey.com. $\mathrm{au} / 2010 / 03 / 17 /$ spinning-the-media-spin-doctors-have-plenty-to-say-in-healthreporting/

Gooch, N, \& Williams-Lahari, L. (2008). Medics and the media: Developing Pacific health journalism. In Singh, S, \& B. Prasad. (Eds), Media and development. Issues and challenges in the Pacific Islands. Fiji: Fiji Institute of Applied Study.

Kippax, S. (2007). Reflections of a social scientist on doing HIV social research, Sydney: The National Centre in HIV Social Research.

Lupton, D., Chapman, S., \& Wong, W. (1993). Back to complacency: AIDS in the Australian press. Health Education Research, 8 (1), 5 -17.

McKee, N., Bertrand, J. \& Benton-Becker, J. (2004). Strategic communication in the HIV/AIDS epidemic. London: Sage Publications.

Mcllwaine, S. (2001). Science and journalism: A Mexican stand-off? Australian Journalism Review, 23 (2), 167-188.

Miller, D., \& Williams, K. (1993). Negotiating HIV/AIDS information: Agenda, media strategies and the news. In J. Eldridge (Ed.), Getting the message: News, truth and power. London: Routledge.

Mooney, C. \& Kirshenbaum, S. (2009). Unpopular science. Retrieved on 14 October, 2012, from http://groups.yahoo.com/group/Net- Gold/message/29734?var=1

Murcott, T. (2009). Science journalism: Toppling the priesthood, Nature, 459 (10), 1054-5.

National AIDS Council Secretariat, (2010). Annual STI, HIV \& AIDS surveillance report. Port Moresby. Papua New Guinea: NACS.

Neilkin, D. (1989). Journalism and science: The creative tension. In M. Moore (Ed.), Health risks and the press: Perspectives on media coverage of risk assessment and health. Washington DC: The Media Institute.

Orange, R. (2008). Beware the spin doctors. Retrieved on 15 February, 2013, from www.pressgazette.co.uk/story.asp? sectioncode $=1 \&$ storycode $=40441$ 
Pew Internet and American Life Project, (2013) Online health 2013. Retrieved on 15 April, 2013, from http://www.pewinternet.org/ /media//Files/Reports/ PIP_HealthOnline.pdf

The Post-Courier (PNG). (2010). 'Sad tale but true in PNG', p6, March 7.

Raward, D. \& Johnston, J. (2009). FM Radio News: Spreading the news or spread too thin? Australian Journalism Review, 31(1), 63-76.

Salleh, A. (2009). Scientists risk becoming 'PR hacks'. Retrieved on 22 March 2013, from www.abc.net.au/science/articles/2009/07/03/2613817.htm

Seale, C. (2002). Media and health. London: Sage.

Smith, S. \& Cohen, D. (2000). Gender, development and the HIV epidemic, Geneva: UNDP.

Solomon, A. (2002). Former editor of The Independent newspaper, interviewed in Port Moresby, PNG, September 18.

Schwitzer, G. (2010). The future of health journalism. Public Health Forum. Retrieved 6 September, 2012, from http:// www.elsevier.de/phf

UNAIDS. (2012). Report on the global AIDS epidemic, Geneva: UNAIDS/WHO.

UNESCO. (2001). Strategy for HIV/AIDS prevention education, Paris: UNESCO.

USC Annenberg. (2012). Reporting on health matters: How an investigative reporting startup raised $\$ 140000$ on kickstarter. Retrieved on 17 March, 2013 from www.reportingonhealth.org/blogs/2012/04/05/matter-how-scitech-investigativereporting-startup-raised-140000-kickstarter/.

Whitehouse, A. (2013) Epidemiology and the media. Retrieved on 14 July, 2013 from $\mathrm{http}: / /$ theconversation.com/epidemiology-and-the-media-15972

Wilson, A. (2012). Bad medical reporting: A history of shooting the messenger. Retrieved on 7 July, 2013 from http://theconversation.com/bad-medicalreporting-a-history-of-shooting-the-messenger-6737

World Health Organisation (1986). The Ottawa charter for health promotion. Geneva: WHO.

Young, E. (2009). On cheerleaders and watchdogs - The role of science journalism. Retrieved 10 August, 2012, from http://scienceblogs.com/notrocketscience/2009/07/on_cheerleaders_and_watchdogs_-_the_role_of_science_journali. php

Dr Trevor Cullen is Associate Professor of Journalism at Edith Cowan University.

t.cullen@ecu.edu.au 